\title{
Struktur Modal dan Determinasi Keputusan Hedging pada Perusahaan Automotive and Allied Products
}

\author{
Meza Rahmadini ${ }^{1}$, Dwi Prastowo Darminto ${ }^{2}$ Suyanto $^{3}$ \\ 1,2 Universitas Pancasila , Jakarta, Indonesia \\ ${ }^{3}$ Sekolah Tinggi Ilmu Ekonomi IPWI, Jakarta, Indonesia
}

INFO ARTIKEL

JEL Classification :

M40, L25

\section{Keywords :}

hedging decisions,

financial distress, liquidity, growth opputurnity, capital structure

\begin{abstract}
This study aims to determine the factors that influence hedging decisions with capital structure as a moderating variable in Manufacturing Companies engaged in the Automotive and Allied Product sector which are listed on the Indonesia Stock Exchange. The period used is 2014 - 2018. The design of this research is quantitative research using secondary data. The sample used in this study amounted to 40 companies. The sampling technique was determined using the purposive sampling method. The analytical method used in this study is the Logistic Regression Method using the Eviews 10 program. Based on the results of the study, it shows that the Financial Distress and Liquidity variables influence the Hedging Decision while the Growth Opportunity does not affect the Hedging Decision. The results also showed that the Capital Structure as a moderating variable had no effect on the relationship between Financial Distress on Hedging Decisions but influenced the relationship between Growth Opportunity on Hedging Decisions and the relationship between Liquidity on Hedging Decisions.
\end{abstract}

\begin{abstract}
ABSTRAK
Penelitian ini bertujuan untuk mengetahui faktor-faktor yang mempengaruhi keputusan hedging dengan struktur modal sebagai variabel moderasi pada Perusahaan Manufaktur yang bergerak pada sektor Automotive and Allied Product yang terdaftar di Bursa Efek Indonesia. Periode yang digunakan adalah tahun 2014 - 2018. Desain penelitian ini adalah penelitian kuantitatif dengan menggunakan data sekunder. Sampel yang digunakan dalam penelitian ini berjumlah 40 perusahaan. Teknik pengambilan sampel ditentukan dengan menggunakan metode purposive sampling. Metode analisis yang digunakan dalam penelitian ini adalah Metode Regresi Logistik dengan menggunakan program Eviews10. Berdasarkan hasil penelitian, menunjukkan bahwa variabel Financial Distress dan Liquidity berpengaruh terhadap Keputusan Hedging sedangkan Growth Opportunity tidak berpengaruh terhadap Keputusan Hedging. Hasil penelitian juga menunjukkan bahwa Struktur Modal sebagai variable moderasi tidak berpengaruh terhadap hubungan antara Financial Distress terhadap Keputusan Hedging namun berpengaruh terhadap hubungan antara Growth Opportunity terhadap Keputusan Hedging dan hubungan antara Liquidity terhadap Keputusan Hedging.
\end{abstract}




\section{Pendahuluan}

Perkembangan perdagangan internasional saat ini telah berkembang pesat. Perkembangan itu terlihat dari semakin banyaknya transaksi bisnis dari pihak-pihak yang berasal dari satu negara misalnya transaksi pembelian barang antar Negara atau yang lebih kita kenal istilah import dan export. Transaksi perusahaan tidak hanya dilakukan secara tunai, akibatnya muncul hutang ataupun piutang yang mengakibatkan perusahaan mengalami kerugian ataupun keuntungan. Melalui struktur modal perusahaan kita bisa mengetahui terkait hutang perusahaan yang diproksikan dengan rasio leverage (DER).

Dalam 5 tahun ini Indonesia mengalami pelemahan nilai rupiah terhadap US dollar. Adapun pergerakan nilai rupiah terhadap dollar bisa dilihat pada gambar berikut :

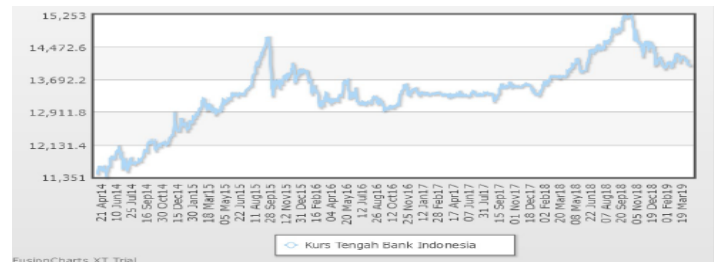

Sumber : (https;//kursdollar.net/, 2019)

\section{Gambar 1. Trend Nilai Rupiah Terhadap Dollar}

Grafik diatas menunjukkan adanya fluktuasi nilai tukar rupiah terhadap dollar. Terlihat nilai tukar rupiah hampir secara terus menerus melemah yang berakibat pada nilai transaksi ekspor atau impor perusahaan dan hutang dollar yang dimiliki perusahaan. Perusahaan akan dirugikan karena mengalami kenaikan.

Menurut Kurniawan (2018) "Hedging adalah salah satu alternatif perusahaan untuk menghindari resiko. Hedging sangat bermanfaat bagi perusahaan yang memiliki usaha dan sering bertransaksi yang berkaitan dengan suku bunga atau nilai tukar. Jika perusahaan mempunyai hutang dalam valuta asing dan suku bunga mengambang, mereka pasti akan terpengaruh oleh suku bunga yang cenderung naik dan nilai tukar yang fluktuatif. Kebutuhan hedging juga dirasakan semakin besar khususnya oleh perusahaan-perusahaan umum yang kerap melakukan ekspor dan impor. Hedging juga dapat mengurangi kemungkinan bangkrut, memungkinkan perusahaan untuk mendapatkan kredit dari kreditor dengan lebih mudah, menjalin kerjasama yang lebih baik dengan pemasok, dan memungkinkan perusahaan untuk mendapatkan pinjaman dengan suku bunga yang lebih rendah karena risiko yang dirasakan oleh pemberi pinjaman lebih rendah.”

Perusahaan Automotive and Allied Products merupakan perusahaan yang lebih sering melakukan transaksi dengan pihak luar negeri. Berikut ditampilkan grafik trend hedging perusahaan sektor Autototive and Allied Product dari tahun 2009 hingga tahun 2018.

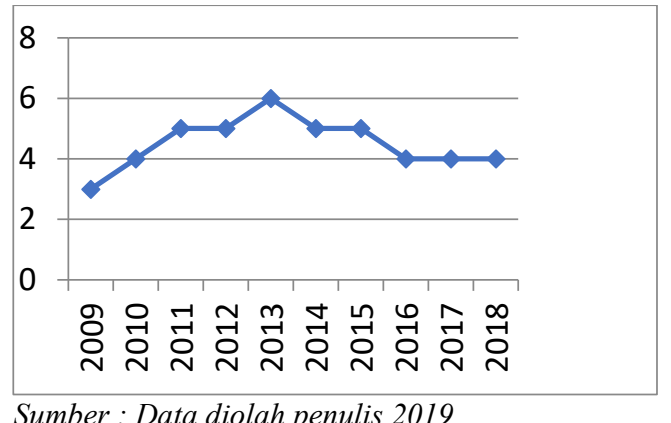

Sumber : Data diolah penulis 2019

\section{Gambar 2. Trend Perusahaan Sektor Autototive and Allied Product yang Menggunakan Hedging Periode 2009-2018}

Berdasarkan gambar di atas, perusahaan sektor Automotive and Allied Product yang menggunakan kebijakan hedging dari tahun 2011 sampai 2018 mengalami penurunan. Terlihat pada tahun 2015 mengalami penurunan dan tidak ada peningkatan hingga tahun 2018.

Beberapa penelitian telah dilakukan untuk mengetahui faktor-faktor yang mempengaruhi hedging dengan instrument derivatif. Pada penelitian yang dilakukan oleh Hartono (2018) menyatakan bahwa "growth opportunity, kebijakan deviden, liquidity tidak memiliki pengaruh secara signifikan terhadap hedging sedangkan firm size memiliki pengaruh secara signifikan terhadap hedging." Sedangkan penelitian yang dilakukan oleh Frorensen (2018) menyatakan bahwa "debt equity ratio dan firm size memiliki pengaruh signifikan terhadap keputusan hedging sedangkan growth opportunity dan liquidity tidak memiliki pengaruh secara signifikan 
terhadap keputusan hedging." Penelitian lain dilakukan oleh Herianti (2018) menyatakan bahwa "liquidity dan financial distress memiliki pengaruh secara signifikan terhadap keputusan hedging sedangkan growth opportunity tidak memiliki pengaruh secara signifikan terhadap keputusan hedging. "

\section{Telaah Teori dan Pengembangan Hipotesis}

\section{Contacting Theory}

Teori kontrak adalah hubungan kontrak antara pemasok dan konsumen faktor-faktor produksi. Hal ini berarti bahwa suatu perhubungan kontrak karena centralize atau adanya hubungan, kontrak antara Anda sebagai konsumen dan berbagai pemasok.

\section{Efficiency Theory}

Efisiensi merupakan hasil perbandingan antara output fisik dan input fisik. Semakin tinggi rasio output terhadap input maka semakin tinggi tingkat efisiensi yang dicapai. Efisiensi juga dapat dijelaskan sebagai pencapaian output maksimum dari penggunaan sumber daya tertentu. Jika output yang dihasilkan lebih besar dari pada sumber daya yang digunakan maka semakin tinggi pula tingkat efisiensi yang dicapai.

\section{Hedging}

Menurut Jiwandhana (2015) "hedging memberi kesempatan bagi trader untuk melindungi diri dari kemungkinan rugi. Hedging diartikan sebagai kebijakan perusahaan dalam meminimalisir risiko fluktuasi valuta asing yang dapat merugikan perusahaan, dengan cara menggunakan instrumen derivatif yaitu future, opsi, swap, dan forward."

\section{Financial Distress dan Keputusan Hedging}

Menurut Rudianto (2013) "financial distress adalah kondisi yang menggambarkan keadaaan sebuah perusahaan yang sedang mengalami kesulitan keuangan, artinya perusahaan berada dalam posisi yang tidak aman dari ancaman kebangkrutan atau kegagalan pada usaha perusahaaan tersebut." $\mathrm{H}_{1}$ : Financial distress berpengaruh terhadap keputusan hedging

\section{Liquidity dan Keputusan Hedging}

Hartono (2017) menyatakan bahwa "semakin tinggi nilai likuiditas maka semakin rendah aktivitas hedging yang dilakukan karena risiko kesulitan keuangan yang muncul cenderung rendah dan sebaliknya."

$\mathrm{H}_{2}$ : Liquidity berpengaruh terhadap keputusan hedging

\section{Growth Opportunity dan Keputusan Hedging}

Menurut Saragih (2017) "semakin tinggi tingkat pertumbuhan suatu perusahaan, maka semakin perlu melakukan kegiatan hedging dalam perusahaan untuk melindungi risiko yang dapat menimbulkan merugikan bagi perusahaan tersebut."

$\mathrm{H}_{3}$ : Growth opportunity berpengaruh terhadap keputusan hedging

\section{Financial distress, Struktur Modal dan Keputusan Hedging}

Struktur modal merupakan keputusan keuangan berhubungan dengan variabel keputusan keuangan yang lainnya. Pengukuran struktur modal pada penelitian ini diproksikan dengan Debt to Equity Rasio (DER). Pada keadaan perusahaan yang mengalami financial distrees akan memungkinkan tingkat leverage perusahaan juga semakin tinggi sehingga keputusan hedging akan menjadi salah satu solusi perusahaan untuk menghindari kebangkrutan.

$\mathrm{H}_{4}$ : Financial distress berpengaruh terhadap keputusan hedging ketika dimoderasi oleh struktur modal

\section{Liquidity, Struktur Modal dan Keputusan Hedging}

Struktur modal dijadikan sebagai moderasi karena untuk memperkuat hubungan liquidity dengan keputusan hedging. Menurut Kasmir (2013) dalam Herianti (2018) menyatakan bahwa "rasio likuiditas merupakan rasio yang menggambarkan kemampuan perusahaan dalam memenuhi kewajiban yang sudah jatuh tempo. Artinya apabila perusahaan ditagih, perusahaan akan mampu untuk memenuhi utang tersebut terutama utang yang sudah jatuh tempo. Dengan kata lain, rasio likuiditas berfungsi untuk menunjukkan atau mengukur kemampuan perusahaan dalam memenuhi kewajibannya yang sudah jatuh tempo, baik kewajiban kepada pihak luar perusahaan maupun di dalam perusahaan." 
$\mathrm{H}_{5}$ : Liquidity berpengaruh terhadap keputusan hedging ketika dimoderasi oleh struktur modal

\section{Growth Opportunity, Struktur Modal dan Keputusan Hedging}

Growth opportunity merupakan salah satu faktor yang mempengaruhi struktur modal perusahaan. Growth Opportunity yang tinggi menunjukkan bahwa perusahaan tersebut memiliki probabilitas untuk tumbuh dan menarik perhatian para investor, sehingga dibutuhkan dana dalam jumlah yang cukup besar untuk membiayai pertumbuhan tersebut dimasa yang akan datang. Semakin besar peluang bertumbuhnya perusahaan akan menimbulkan semakin banyak risiko dan hedging merupakan salah satu solusi untuk meminimalisasi risiko tersebut.

$\mathrm{H}_{6}$ : Growth opportunity berpengaruh terhadap keputusan hedging ketika dimoderasi oleh struktur modal

\section{Metode Penelitian}

Penelitian ini menerapkan pendekatan kuantitatif. Pendekatan yang menggunakan data yang berupa angka merupakan pendakatan kuantitatif. Tujuan dari penelitian ini adalah mencari pengaruh antar variabel. Populasi didalam penelitian ini adalah perusahaan sektor Automotive And Allied Product yang listing didalam BEI pada tahun 2014-2018 sebanyak 40 sampel. Data yang digunakan merupakan data sekunder yang didapatkan dalam laporan keuangan yang diperoleh dari website BEI.

\section{Definisi Operasional Variabel Keputusan Hedging}

Jiwandhana (2015) menyatakan bahwa "kebijakan perusahaan dalam meminimalisir risiko fluktuasi valuta asing yang dapat merugikan perusahaan, dengan cara menggunakan instrumen derivatif yaitu future, opsi, swap, dan forward." Pengukurannya menggunakan variabel dummy. 1 = Melakukan Hedging dan $0=$ Tidak Melakukan Hedging.

\section{Finansial Distress}

Menurut Rudianto (2013) "kondisi yang menggambarkan keadaaan sebuah perusahaan yang sedang mengalami kesulitan keuangan)." Pengukurannya menggunakan Altman Z-core.
Bentuk persamaan untuk model Alman ZScore adalah sebagai berikut :

$$
\mathrm{Z}=\mathrm{X} 1+\mathrm{X} 2+\mathrm{X} 3+\mathrm{X} 4+\mathrm{X} 5
$$

Dimana :

$$
\begin{aligned}
& \mathrm{Z}=\text { Overall Index of Corporate Health } \\
& \mathrm{X} 1=\frac{\text { Working Capital }}{\text { Total Assets }} \\
& \mathrm{X} 2=\frac{\text { Retairned Earnings }}{\text { Total Assets }} \\
& \mathrm{X} 3=\frac{\text { Earnings Before Interest Taxes }}{\text { Total Assets }} \\
& \mathrm{X} 4=\frac{\text { Market Value of Equity }}{\text { Book Value of Total Debt }} \\
& \mathrm{X} 5=\frac{\text { Sales }}{\text { Total Assets }}
\end{aligned}
$$

\section{Liquidity}

Muliawan (2017) menyatakan bahwa "menilai kemampuan perusahaan dalam menyelesaikan hutang jangka pendek." Pengukurannya menggunakan Current Rasio.

$$
\mathrm{CR}=\frac{\text { Current Assets }}{\text { Current Liabilities }}
$$

\section{Growth Opportunity}

Menurut Herianti (2018) "peluang pertumbuhan perusahaan di masa depan." Untuk pengukurannya melihat dari pertumbuhan aset menggunakan rumus sebagi berikut :

$\mathrm{GO}=\frac{\text { Total Aset }(\mathrm{t})-\text { Total Aset }(\mathrm{t}-1)}{\text { Total Aset }(\mathrm{t}-1)}$

\section{Struktur Modal}

Menurut Mardiyanto (2009) "struktur modal merupakan komposisi dan proporsi utang jangka panjang dan ekuitasyang ditetapkan perusahaan." Pengukurannya menggunakan Rasio Leverage dengan rumus dibawah ini:

DER $=\frac{\text { Total Utang }}{\text { Total Ekuitas }}$

\section{Firms Size}

Merupakan Keseluruhan total aset (Fernando Hartono, 2017). Pengukurannya menggunakan rumus sebagai berikut :

Firm Size $=\operatorname{Ln}($ Total Asset $)$ 


\section{Hasil Penelitian dan Pembahasan}

Penelitian ini memiliki jumlah target Analisis menggunakan regresi logistik dengan melakukan berbagai pengujian, yaitu uji kelayakan model, uji keseluruhan model, uji determinasi, uji $\mathrm{T}$, uji estimasi parameter dan interpretasinya

\section{Uji Regresi Logistik}

Dalam Uji Kelayakan Model, Nilai HL Statictics harus $>0,05$ baru dikatakan model regresi tersebut layak. Pada penelitian ini menunjukkan bahwa besarnya nilai HL Statistics sebesar 7.7655 dengan probabilitas signifikansi 0,4567 yang nilainya di atas 0,05 . Dengan demikian dapat disimpulkan bahwa model dapat diterima dan layak.

Pada Uji Keseluruhan Model dinilai dari Likehood L. Dapat dilihat bahwa nilai LR Statistic sebesar 28.87601 dengan probabilitas sebesar 0.000152. Nilai ini lebih kecil dari tingkat signifikansi uji sebesar 0.05 sehingga kita dapat menolak hipotesis nol yang menyatakan bahwa tidak ada variabel bebas yang berpengaruh signifikan terhadap variabel tak bebas. Dengan demikian, maka dengan tingkat kepercayaan 95\% dapat disimpulkan bahwa minimal terdapat satu variabel bebas yang berpengaruh signifikan terhadap variabel tak bebas.

Pada Uji Determinasi menunjukkan nilai R-squared sebesar 0,545602 yang berarti variabilitas variabel dependen yang dapat dijelaskan oleh variabilitas variabel independen sebesar $54,56 \%$, sisanya $45,44 \%$ dijelaskan oleh variabel lainnya yang tidak dimasukkan dalam model regresi.

\section{Uji Hipotesis}

Tabel 1. Uji Estimasi Parameter

\begin{tabular}{|l|l|l|l|}
\hline & \multicolumn{1}{|c|}{ B } & Sig & \multicolumn{1}{c|}{ Ket } \\
\hline C & -54.01407 & 0.0344 & \\
\hline FD & -1.752033 & 0.0330 & Berpengaruh \\
\hline LQD & 2.096247 & 0.0119 & Berpengaruh \\
\hline GO & -6.784377 & 0.3176 & $\begin{array}{l}\text { Tdk } \\
\text { Berpengaruh }\end{array}$ \\
\hline FZ & 1.890060 & 0.0324 & $\begin{array}{l}\text { Tdk } \\
\text { Berpengaruh }\end{array}$ \\
\hline FD_SM & 0.991835 & 0.4258 & Berpengaruh \\
\hline LQD_SM & -2.674740 & 0.0368 & Berpengaruh \\
\hline GO_SM & 4.164260 & 0.0991 & Berpengaruh \\
\hline
\end{tabular}

Sumber : Hasil Output Eviews 2020

\section{Pengaruh Financial Distress Terhadap Keputusan Hedging}

Pengaruh finansial distress terhadap keputusan hedging memiliki koefisian regresi sebesar -1,752033 dengan probabilitas 0,0330 dengan signifikan pada alpha $0,5 \%$. Hal ini berarti Hipotesis diterima, bahwa financial distress berpengaruh terhadap keputusan hedging.

Seperti yang dijelaskan Rudianto dalam Herianti (2018) "financial distress adalah kondisi yang menggambarkan keadaaan sebuah perusahaan yang sedang mengalami kesulitan keuangan, artinya perusahaan berada dalam posisi yang tidak aman dari ancaman kebangkrutan atau kegagalan pada usaha perusahaaan tersebut. Keputusan untuk melakukan hedging bisa dijadikan solusi bagi perusahaan untuk menghindari risiko tersebut. Semakin tinggi tingkat finansial distress perusahaan maka akan semakin tinggi peluang perusahaan melakukan hedging."

Hasil penelitian ini konsisten dengan hasil penelitian yang dilakukan oleh Aditya (2019) dan Herianti dan Juwita (2018) yang menyatakan bahwa "financial distress berpengaruh secara signifikan terhadap keputusan hedging."

\section{Pengaruh Liquidity Terhadap Keputusan Hedging}

Pengaruh liquidity terhadap keputusan hedging memiliki koefisian regresi sebesar 2,096247 dengan probabilitas 0,0119 dengan signifikan pada alpha $0,5 \%$. Hal ini berarti Hipotesis diterima, bahwa liquidity berpengaruh terhadap keputusan hedging.

Menurut Hartono (2017) "semakin tinggi nilai likuiditas maka semakin rendah aktivitas hedging yang dilakukan karena risiko kesulitan keuangan yang muncul cenderung rendah dan sebaliknya." Hani (2015) menyatakan bahwa "secara spesifik likuiditas mencerminkan ketersedian dana yang dimiliki perusahaan guna memenuhi semua hutang yang akan jatuh tempo." Semakin tinggi rasio berarti perusahaan semakin mampu dalam memenuhi kewajiban.

Hasil penelitian ini konsisten dengan penelitian yang dilakukan oleh Muliawan dan Cholid (2018) bahwa "liquidity memiliki 
pengaruh signifikan negatif pada keputusan hedging."

\section{Pengaruh Growth Opportunity Terhadap Keputusan Hedging}

Pengaruh growth opportunity terhadap keputusan hedging memiliki koefisian regresi sebesar -6,784377 dengan probabilitas 0,3176 dengan signifikan pada alpha $0,5 \%$. Hal ini berarti Hipotesis ditolak, bahwa growth opportunity tidak berpengaruh terhadap keputusan hedging.

Growth opportunity atau peluang pertumbuhan perusahaan dapat didefinisikan sebagai peluang investasi perusahaan yang dapat meningkatkan nilai perusahaan di masa yang akan datang. Menurut Saragih (2017) "peluang pertumbuhan (growth opportunity) adalah peluang pertumbuhan suatu perusahaan di masa depan. Kesempatan pertumbuhan perusahaan yang tinggi akan menunjukkan nilai pasar yang semakin tinggi di antara perusahaan lain. Semakin tinggi tingkat pertumbuhan suatu perusahaan, maka semakin perlu melakukan kegiatan hedging dalam perusahaan untuk melindungi risiko yang dapat menimbulkan merugikan bagi perusahaan tersebut."

Hasil yang tidak signifikan pada variabel growth opportunity dapat disebabkan karena peluang pertumbuhan perusahaan terlalu rendah dan tidak stabil sehingga tidak membutuhkan aktivitas hedging untuk mengantisipasi risiko. Hasil penelitian ini sejalan dengan penelitian yang Guniarti (2014) dan Florensen,dkk (2018) menunjukkan bahwa "growth opportunity tidak berpengaruh signifikan terhadap keputusan hedging."

\section{Pengaruh Financial Distress Terhadap Keputusan Hedging yang Dimoderasi oleh Struktur Modal}

Pengaruh financial distress terhadap keputusan hedging dengan dimoderasi oleh struktur modal memiliki koefisian regresi sebesar 0,991835 dengan probabilitas 0,4258 dengan signifikan pada alpha $0,5 \%$. Hal ini berarti Hipotesis ditolak, bahwa financial distress tidak berpengaruh terhadap keputusan hedging dengan dimoderasi oleh struktur modal.

Struktur modal merupakan salah satu keputusan keuangan yang kompleks karena berhubungan dengan variabel keputusan keuangan yang lainnya. Pengukuran struktur modal pada penelitian ini diproksikan dengan Debt to Equity Rasio (DER). Menurut Ang dalam Muksal (2017) "semakin tinggi nilai debt to equity ratio menunjukkan semakin besar total utang terhadap total ekuitas yang artinya juga menunjukkan ketergantungan perusahaan terhadap pihak luar (kreditur), sehingga perusahaan juga akan menanggung risiko yang tinggi pula." Guniarti (2014) menyatakan bahwa "semakin tinggi leverage maka akan semakin besar tindakan hedging yang dilakukan untuk mengurangi dampak buruk risiko sehingga aktivitas hedging berhubungan positif dengan leverage."

Pada keadaan perusahaan yang mengalami financial distrees akan memungkinkan tingkat leverage perusahaan juga semakin tinggi sehingga keputusan hedging akan menjadi salah satu solusi perusahaan untuk menghindari kebangkrutan. Namun nilai DER yang yang tinggi belum tentu perusahaan mengambil kebijakan lindung nilai atau hedging kejadian ini disebabkan karena perusahaan yang melakukan atau mempunyai utang yang tidak didominasi dengan kurs valas atau dengan kata lain perusahaan memiliki utang rupiah yang lebih dominan, dengan begitu kebijakan hedging belum perlu diterapkan perusahaan.

Hasil penelitian ini sejalan dengan penelitian yang dilakukan oleh Aditya (2019) "bahwa leverage tidak berpengaruh siginifikan terhadap penggunaan instrument derivative sebagai pengambil keputusan hedging."

Dapat disimpulkan bahwa variabel moderasi struktur modal memperlemah hubungan antara financial distress dalam mempengaruhi perusahaan untuk mengambil keputusan hedging.

\section{Pengaruh Liquidity Terhadap Keputusan Hedging yang Dimoderasi oleh Struktur Modal}

Pengaruh liquidity terhadap keputusan hedging dengan dimoderasi oleh struktur modal memiliki koefisian regresi sebesar 2,674740 dengan probabilitas 0,0368 dengan signifikan pada alpha $0,5 \%$. Hal ini berarti Hipotesis diterima, bahwa liquidity berpengaruh terhadap keputusan hedging dengan dimoderasi oleh struktur modal.

Pengukuran struktur modal pada penelitian ini menggunakan debt to equity ratio. Menurut 
Kurniawan (2018) "DER merupakan ratio yang menunjukkan perbandingan antara utang dengan ekuitas dalam pendanaan perusahaan dan menunjukan kemampuan modal sendiri perusahaan untuk memenuhi segala kewajibannya".

Struktur modal dijadikan sebagai moderasi karena untuk memperkuat hubungan liquidity dengan keputusan hedging. Menurut Kasmir dalam Herianti (2018) "rasio likuiditas merupakan rasio yang menggambarkan kemampuan perusahaan dalam memenuhi kewajiban yang sudah jatuh tempo. Artinya apabila perusahaan ditagih, perusahaan akan mampu untuk memenuhi utang tersebut terutama utang yang sudah jatuh tempo. Dengan kata lain, rasio likuiditas berfungsi untuk menunjukkan atau mengukur kemampuan perusahaan dalam memenuhi kewajibannya yang sudah jatuh tempo, baik kewajiban kepada pihak luar perusahaan maupun di dalam perusahaan."

Penelitian ini sejalan dengan penelitian yang dilakukan oleh Kinasih dan Mahardika (2019) yang menyatakan bahwa "liquidity dan DER mempunyai pengaruh signifikan terhadap keputusan hedging." Dapat disimpulkan bahwa variabel moderasi struktur modal memberikan pengaruh signifikan antara liquidity dalam mempengaruhi perusahaan untuk mengambil keputusan hedging. Pengaruh yang ditimbulkan tidak terlalu jauh berbeda ketika liquidity berpengaruh terhadap keputusan hedging tanpa adanya variabel moderasi.

\section{Keputusan Hedging yang Dimoderasi oleh Struktur Modal}

Pengaruh growth opportunity terhadap keputusan hedging dengan dimoderasi oleh struktur modal memiliki koefisian regresi sebesar 4,164260 dengan probabilitas 0,0991 dengan signifikan pada alpha $10 \%$. Hal ini berarti Hipotesis diterima, bahwa growth opportunity berpengaruh terhadap keputusan hedging dengan dimoderasi oleh struktur modal.

Menurut Saragih (2017) "Growth opportunity merupakan salah satu faktor yang mempengaruhi struktur modal perusahaan. Growth Opportunity yang tinggi menunjukkan bahwa perusahaan tersebut memiliki probabilitas untuk tumbuh dan menarik perhatian para investor, sehingga dibutuhkan dana dalam jumlah yang cukup besar untuk membiayai pertumbuhan tersebut dimasa yang akan datang."

Menurut Mai dalam Hermuningsih (2013) "semakin tingginya perusahaan mengalami growth opportunity, maka aktivitas hedging yang dilakukan semakin tinggi, dikarenakan perusahaan yang mengalami kesempatan pertumbuhan akan melindungi perusahaannya dari risiko."

Menurut Kurniawan (2015) "semakin tinggi leverage atau DER yang dibebankan sebuah perusahaan maka menunjukkan ketergantungan perusahaan tersebut terhadap utang jauh lebih tinggi dibandingkan ekuitas pemegang saham, sehingga menunjukkan tingkat risiko gagal bayar yang tinggi pula. Jika kondisi seperti itu terjadi maka tindakan yang harus dilakukan adalah menerapkan kebijakan hedging dengan tujuan meminimalkan risiko, jika tidak maka peluang risiko kebangkrutan juga semakin besar, sehingga perusahaan perlu mengantisipasi dengan cara melakukan hedging. Ditambah lagi dengan kondisi pertumbuhan perusahaan yang rendah akan semakin memberikan peluang bagi perusahaan untuk melakukan aktivitas hedging. "

Hasil penelitian ini sejalan dengan penelitian yang dilakukan Kurniawan (2018) bahwa "DER berpengaruh signifikan positif terhadap keputusan hedging. Maka dapat disimpulkan bahwa variabel moderasi struktur modal memperkuat hubungan antara growth opportunity dalam mempengaruhi perusahaan untuk mengambil keputusan hedging."

\section{Kesimpulan, Keterbatasan dan Implikasi Hasil Penelitian}

Financial distress dan liquidity berpengaruh terhadap keputusan hedging sedangkan growth opportunity tidak berpengaruh terhadap keputusan hedging. Financial distress tidak berpengaruh terhadap keputusan hedging ketika dimoderasi oleh struktur modal sedangkan liquidity dan growth opportunity berpengaruh terhadap keputusan hedging ketika dimoderasi oleh struktur modal.

Penelitian ini memiliki keterbatasan yaitu jumlah perusahaan yang diteliti hanya sebatas perusahaan manufaktur yang bergerak pada sektor Automotive and Allied Product dan variabel yang mempengaruhi keputusan hedging pada penelitian ini hanya terbatas pada 
financial distress, liquidity, growth opportunity, firm size, dan struktur modal. Masih ada beberapa variabel lain yang belum dimasukkan dan memiliki kemungkinan untuk berpengaruh terhadap keputusan hedging.

Saran untuk penelitian selanjutnya adalah agar dapat memasukkan semua sektor pada perusahaan manufaktur karena perusahaan ini lebih sering melakukan transaksi dengan menggunakan mata uang asing dan memiliki lebih banyak resiko kerugian. Selain itu peneliti selanjutnya juga bisa menambah variabel lain yang mempengaruhi keputusan hedging misalnya faktor dari eksternal perusahaan seperti tingkat inflasi dan tingkat suku bunga untuk melihat pengaruhnya terhadap keputusan hedging yang dilakukan perusahaan.

\section{Daftar Pustaka}

Aditya, A. T., \& Asandimitra, N. (2019). Pengaruh Leverage, Likuiditas, Market to Book Value, Financial Distress dan Firm ize terhadap Keputusan Hedging Sektor Consumer Goods Industry Periode 2011-2016. Jurnal Ilmu Manajemen, 7(2), 334-343.

Florensen, K., Cholid, I., \& Sugara, K. (2018). Analisis Pengaruh Debt Equity Ratio, Firm Size, Growth Opportunity, Dan Liquidity Ratio Terhadap Pengambilan Keputusan Hedging Pada Perusahaan Yang Terdaftar Di Kompas 100 Periode 2015-2017.

Guniarti, F. (2014). Faktor-Faktor Yang Mempengaruhi Aktivitas Hedging Dengan Instrumen Derivatif Valuta Asing. Jurnal Dinamika Manajemen, 5(1), 64-79. https://doi.org/10.15294/jdm.v5i1.3651.

Hartono, F., \& Cholid, I. (2018). Analisis Pengaruh Growth Opportunity, Kebijakan Dividen, Liquidity, dan Firm Size Terhadap Aktivitas Hedging pada Sektor Transportasi, Infrastruktur dan Utilities yang Terdaftar $\mathrm{Di}$ BEI Periode 2014-2017.

Herianti, S., \& Juwita, R. (2018). Pengaruh Liquidity, Financial Distress, Growth Opportunity dan Kepemilikan Institusional Terhadap Keputusan Hedging pada Sektor Manufaktur yang Terdaftar di Bursa Efek Indonesia Periode 2015-2017 Syenni. 1-13.

Hermuningsih, S. (2013). Pengaruh profitabilitas, growth opportunity, struktur modal terhadap nilai perusahaan pada perusahaan publik di Indonesia. Buletin ekonomi moneter dan perbankan, 16(2), 127148.

Jiwandhana, R. S. P., \& Triaryati, N. (2016). Pengaruh Leverege Dan Profitabilitas Terhadap Keputusan Hedging Perusahaan Manufaktur Indonesia. E-jurnal Manajemen Universitas Udayana, 5(1).

Kinasih, R., \& Mahardika, D. P. K. (2019). Pengaruh Likuiditas, Leverage, dan Nilai Tukar Rupiah terhadap Penggunaan Instrumen Derivatif sebagai Keputusan Hedging. Jurnal Ilmiah MEA (Manajemen, Ekonomi, \& Akuntansi), 3(1), 63-80.

Prasetyo Kurniawan, D. (2018). Analisis Faktor Yang Mempengaruhi Penggunaan Instrumen Derivatif Sebagai Pengambilan Keputusan Hedging Pada Perusahaan Sektor Keuangan Yang Terdaftar Di Bei Periode 20112015. Jurnal Ilmu Manajemen (JIM), 6(1).

Muksal,. (2017). Pengaruh DEBT EQUITY RATIO (DER) terhadap Harga Saham Syariah (Studi pada Pasar Sekunder Jakarta Islamic Index(JII)". Jurnal perbankan Syriah Universitas Serambi, Mekkah. 1(1), 1-25.

Muliawan, F., \& Cholid, I. (2018). Analisa Faktor Yang Mempengaruhi Keputusan Hedging Dengan Instrumen Derivatif Pada Perusahaan Perbankan Yang Terdaftar Di BEI Periode 2013 - 2017.

Putro, S. H., \& Chabachib, M. (2012), Analisis Faktor Yang Mempengaruhi Penggunaan Instrumen Derivatif Sebagai Pengambilan Keputusan Hedging. Diponegoro Business Review, 1(1), 1-11.

Saragih, F. (2017). Pengaruh growth opportunity, firm size, dan liquidity terhadap keputusan hedging pada perusahaan perban kan indonesia. Jurnal Ilmu Manajemen (JIM), 5(2).

Sutarja, W., \& Cholid, I. (2018). Analisis Pengaruh Debt To Equity Ratio , Interest Covarage Ratio , Managerial Ownership , dan Market To Book Value Terhadap Pengambilan Keputusan Hedging pada Perusahaan Sektor Terdaftar di Bursa Efek Indonesia Periode 2015-2017. 1-16.

Https;//kursdollar.net/. (2019). Grafik Trend Kurs US Dollar - USD Grafik Trend Kurs US Dollar - US 